DOI: 10.20472/EFC.2018.010.007

\author{
ANDREA CECRDLOVA \\ University of Economics in Prague, Czech Republic
}

\title{
THE FOREIGN EXCHANGE INTERVENTIONS OF THE CNB AS AN UNCONVENTIONAL INSTRUMENT OF MONETARY POLICY
}

\begin{abstract}
:
During the last crisis monetary authorities hit zero interest rates and as a result they began to use less standard instruments. However, they failed to meet the declared inflation target for a long time. The Czech National Bank (CNB) decided to use the unconventional instrument in November 2013 when the exchange rate commitment was introduced. The aim of the paper is to evaluate the decision to use the exchange rate commitment with regard to its potential side effects. The most significant side effect is the enormous amount of foreign exchange reserves, which, due to the appreciation of the domestic currency, can get the CNB into more cumulative negative values than it already is.
\end{abstract}

\section{Keywords:}

CNB, monetary policy, unconventional monetary instruments, foreign exchange interventions, foreign exchange reserves.

JEL Classification: E31, E52, E58 


\section{Introduction}

The credibility of central banks (CBs) is very important for the achievement of their fundamental (and not only fundamental) objectives, because without confidence they cannot influence inflation expectations and therefore they need to use more, or even stronger, monetary-policy instruments to achieve their goals. This was the thesis universally acknowledged by the world academic community before the emergence of the last crisis.

The global crisis, which has fully exploded in 2008, has shown that it can have a significant impact in the long run on the credibility and excessive independence of the CBs. Supervisory or monetary authorities have not always fulfilled their role and have even begun to counterbalance the lack of counter-cyclical role of fiscal policy. During the last crisis monetary authorities hit zero interest rates and as a result they began to use less standard instruments. However, they failed to meet the declared inflation target for a long time. The Czech National Bank (CNB) decided to use the unconventional instrument in November 2013 when the exchange rate commitment was introduced. The main reason was fear of a deflationary spiral.

\section{Unconventional Instruments of Monetary Policy}

\subsection{Zero Lower Interest Rate Limit}

Foreign exchange interventions are especially typical for fixed rate regimes. However, the use of this instrument may be inevitable even in the inflation targeting regime in case of a reduction of the basic interest rates on so-called "technical zero".

As a result of the longest recession in the history of the Czech Republic, the CNB has decided to cut interest rates to technical zero on November 2, 2012.

For further relaxation of the monetary conditions on November 7, 2013, the CNB accepted a commitment of foreign exchange interventions in order to weak the Czech crown and keep it at the level of 27 CZK/EUR (CNB, 2017e).

Table 1: Current settings of key interest rates announced by the CNB

\section{INTEREST RATES}

\begin{tabular}{|l|}
\hline 2T Repo Rate \\
\hline Discount Rate \\
\hline
\end{tabular}

Lombard Rate

\section{INTEREST RATE FROM}

2.11.2012

$0,05 \%$

$0,05 \%$

$0,25 \%$
INTEREST RATE FROM

3.11.2017

$0,5 \%$

Source: CNB (2017e), own processing

${ }^{1}$ Key two-week repo rate for repo operations with a maturity of 14 days. 
At that time fiscal and monetary policy mismatches occurred when government measures to consolidate public finances partly negated the CNB's efforts to release monetary conditions, while tax hikes hampered domestic demand, helping to deepen the cyclical downturn in the economy (Mlčochová, 2012).

The exchange rate commitment was abandoned by the CNB despite the previously announced exits in April 2017. Subsequently the CNB on November 3, 2017, has increased interest rates (2T repo rate and Lombard rate), thus bounced from the zerobottom level.

\subsection{Relaxation of Monetary Conditions}

The basic expectations of the CNB can be formulated into two points:

1. Suppressing deflationary tendencies,

2. Stabilization of the price level.

The CNB expected, without its intervention and relaxation of the MP, the threat of significant strengthening of the Czech crown and thereby interrupting the relatively stable exchange rate and, as a result, economic development.

Figure 1: Development of GDP Growth in 2006-2016

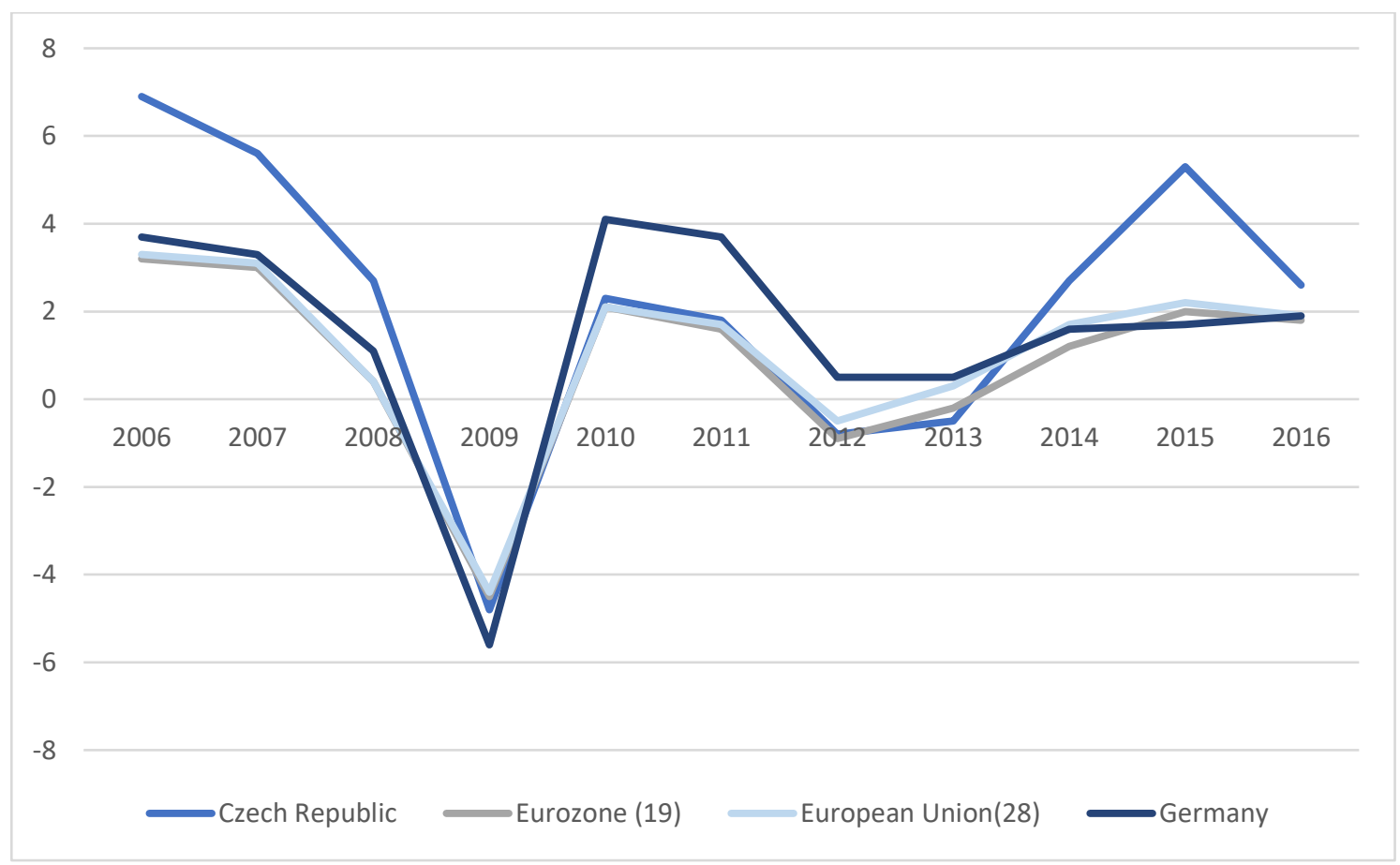

Source: OECD (2017), own processing

As a result of the global crisis in 2008 the growth of the Czech economy slowed significantly and the following year the Czech economy fell by more than $4 \%$. This phenomenon was typical for the development of the entire EU, including Germany (the largest trading partner of Czech Republic). During 2010-2011 there was a gradual recovery of the economy which started to weaken again in the next two years. At the 
time of the beginning of foreign exchange interventions, however, the Czech economy turned around and started to grow.

Figure 2: Evolution of Wages and Unemployment in the Czech Republic

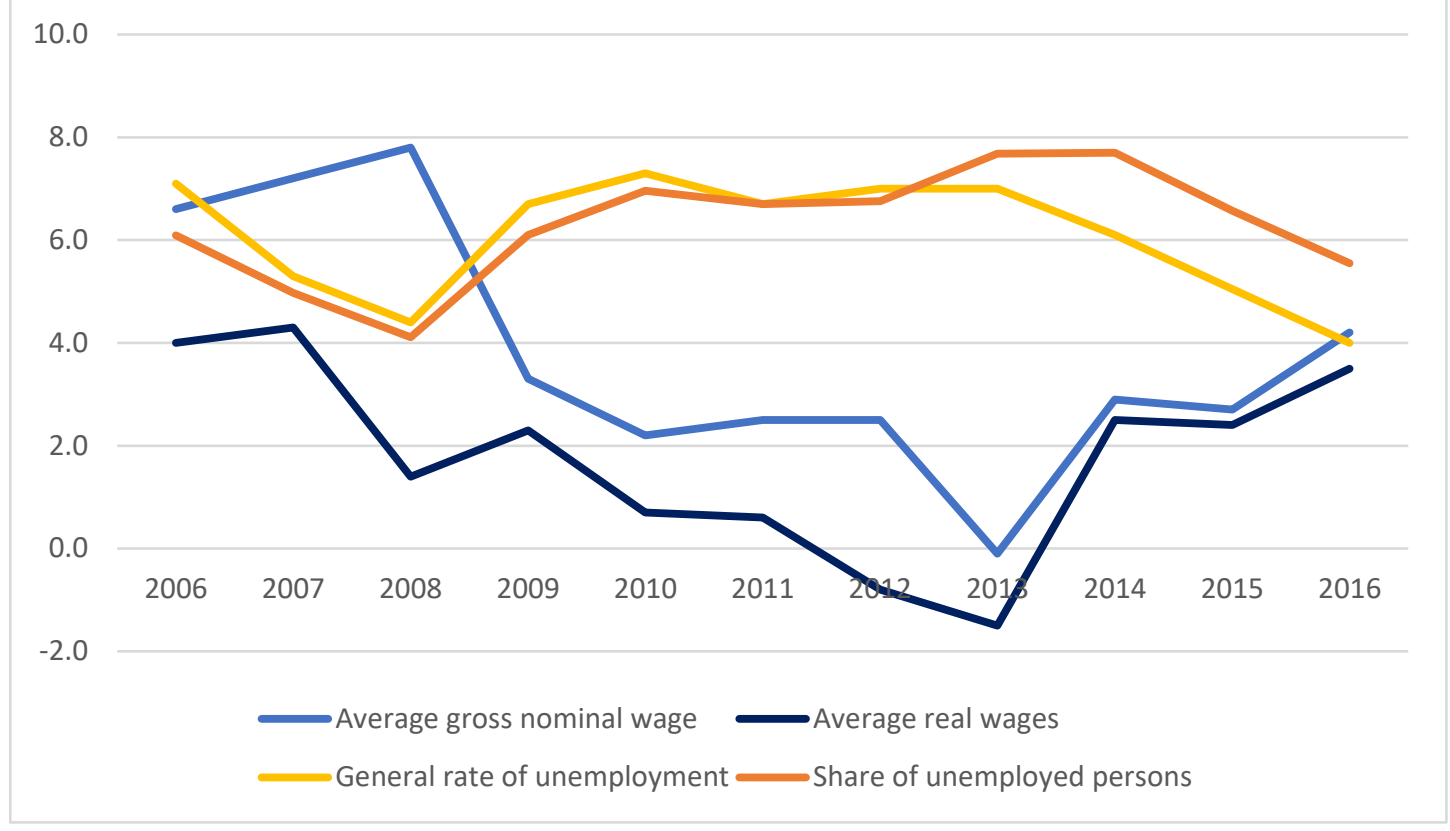

Source: CZSO (2017b), own processing

The above-mentioned slump has led to an unfavourable increase in unemployment, a drop in income, and hence household consumption, and last but not least, a fall in corporate profits and investments.

The decline in wages was reflected on the demand side, which is significantly more difficult for MP. The MP could not have been effective in the context of economic recovery or could only have had a partial impact.

\section{Was Deflation Really a Threat?}

Critics of the CNB's foreign exchange interventions base their criticism on two claims on topic deflation.

1) No deflationary spiral in the Czech Republic threatened, at most short-term.

2) But if deflation had come, deflation would be "good", just like during the industrial revolution.

It should be noted that the foreign exchange interventions, by means of which the CNB realized the exchange rate commitment, were initiated before it was established whether deflation is the case of the Czech Republic. As the former member of the Bank Board of CNB Eva Zamrazilová noted, concerns about deflation were unjustified. "The recession-deflationary spiral, when consumers drop their purchases with a fall in the 
price level, with the fact that the commodities are still cheaper, never grew up here (Czech Press Office, 2016)." A similar opinion has also the former member of Bank Board Pavel Řežábek.

Here, it is important to refer to the crisis years of 2014 and 2015, where the influence of regulated prices was observable, which pushed down overall inflation. It was, therefore, a supply deflation, by other words positive for the economy, not harmful.

The price drop in the regulated basket was the largest in 2014. The impact of energy prices was the most noticeable and reflected the expected decrease in electricity and gas prices. Worth mentioning was also the reduction of the health care item, which was mainly due to the cancellation of the fee for hospital stay (CZK 100). The influence of telecommunications was also evident, where the introduction of unlimited mobile tariffs in 2013 was still observable. "If we find out exactly which prices dropped the most, that is electricity and gas with an impact on inflation -0.8 p. p. They pull inflation down. Without this impact inflation is above one percent and there would be no drama (Zavadilová, 2014)." With regard to the health and telecommunications, the influence of regulated prices on inflation was indeed significant because it exceeded the value of $1 \mathrm{p} . \mathrm{p}$.

It is important to note that the deflation can be modelled as a credibility problem (Eggertsson, 2006). In the long run, the situation in which the inflation is significantly lower than the inflation target can be a major problem for the national economy. The inflation expectations of economic operators are set in accordance with the inflation target. If the CB loses its ability to anchor these expectations, the impact on the real economy can be devastating (Christelis \& Georgarakos \& Jappelli \& Roij, 2016). ${ }^{2}$

\section{Use of Foreign Exchange Interventions by Different Views}

From the point of view of the economic subjects of both importers and exporters, the balance of economic competition was undermined. Anchoring CZK to EUR under pressure of its appreciation it has artificially created a comparative advantage for Czech exporters compared to Czech importers whom the inputs increased.

It should be noted that the Czech Republic, while being export-oriented, is also highly import-intensive, it is even the fifth most demanding country in the EU as regards the imported goods. In proportion to its GDP, the Czech Republic imports almost $80 \%$, which is a considerable import dependency (CZSO, 2013).

\footnotetext{
2 The deflation bias is closely related to a common objection to Krugman's policy proposal for the BOJ. To battle deflation he suggested that the BOJ should announce an inflation target of $5 \%$ for 15 years. Responding to this proposal, Kunio Okina, director of the Institute for Monetary Studies at the BOJ, said in DJN (1999): "Because shortterm interest rates are already at zero setting an inflation target of say $2 \%$ would not carry much credibility." Similar objections were raised by economists such as, e.g., Dominiguez (1998), Svensson (2001), and Woodford (1999).
} 
Recommendations for the application of foreign exchange interventions were received by the CNB from international organizations such as the OECD and the International Monetary Fund (IMF), which drew attention to the use of this instrument

in connection with the relaxation of the MP.

However, the deliberate weakening of the Czech crown was criticized by trade unions, which mainly relied on higher prices of imported goods and a low rate of wage growth.

The view of the industry and transport union, where the number of companies is export-oriented, was rather positive with respect to the exporters because their foreign demand grew at that time (Čížek, 2013).

However, the effect of foreign exchange interventions was limited in this area.

1. Part of export sales is held by most firms secured against exchange rate fluctuations.

2. Import intensity of a number of export industries, such as automotive companies.

Securing companies against exchange rate fluctuations is a common matter today, and according to the survey, the value of collateral at the time of foreign exchange intervention was around 1/3. As a result of verbal interventions by the CNB the ratio of the value of firms secured against exchange rate fluctuations diminished, but not remarkably (Čížek, 2013).

As far as the import intensity of the economy is concerned, it is important to mention the incoming revenues and costs in foreign currencies that caused the resulting effect to be significantly smaller than the promoters of the interventions assumed.

The import intensity of Czech export is growing steadily, when from the original $45.1 \%$ in 2011 it reached $46.6 \%$ in 2014 (Eurostat, 2017). This means that exchange rate gains from the exchange rate commitment were more or less balanced by exchange rate losses.

\subsection{Revival of the Economy}

While GDP declined throughout the years 2011 and 2012, it started to grow steadily from the first quarter of 2013. It can be said that the change in the trend and the beginning of economic growth could not have been the result of only and only exchange rate interventions, since it started about 2-3 quarters before the exchange rate commitment was even introduced. 


\section{Figure 3: Evolution of inflation rate and GDP growth in 2011-2016}

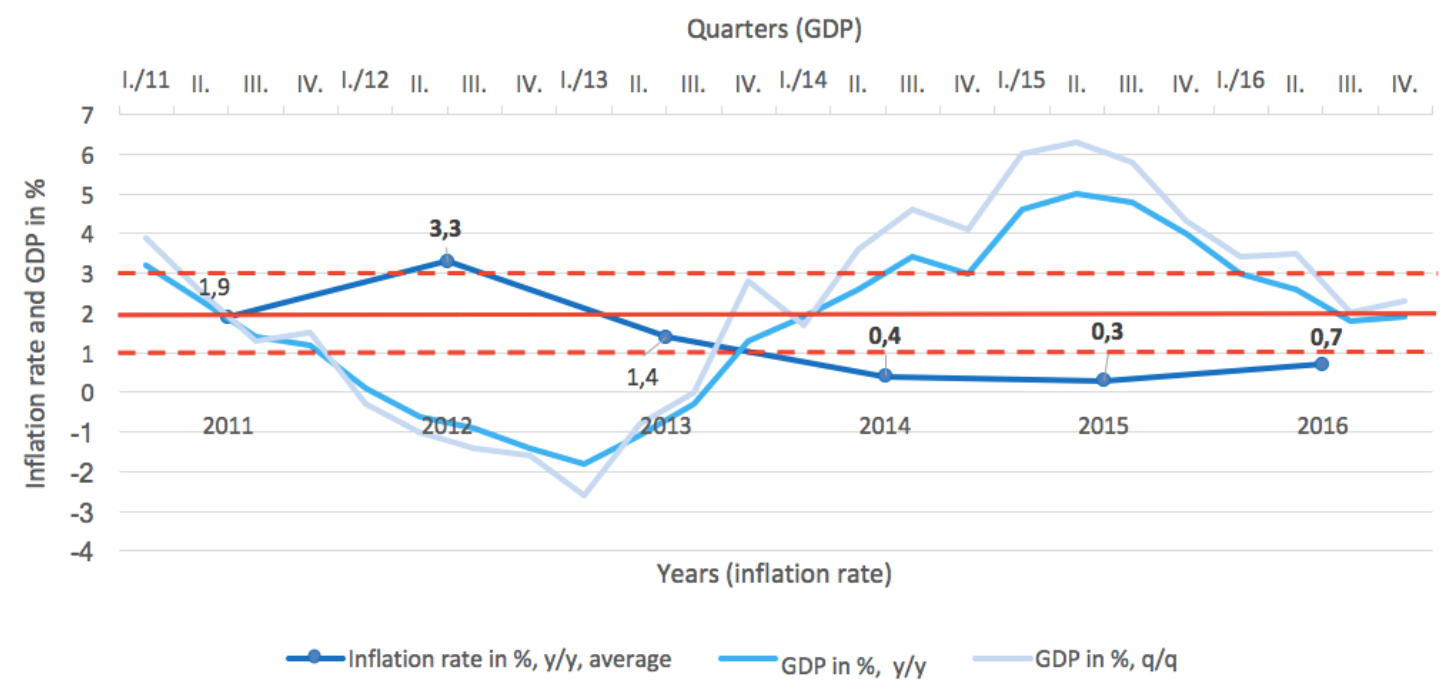

Source: CSO, Main macroeconomic indicators, own processing

The impact of the exchange rate commitment cannot be ruled out, but also with regard to the short transmission, it can be argued that the development of GDP in 2011-2016 was due in particular to the development of the economic cycle.

\section{How Did the Last Crisis Affect the Foreign Exchange Reserves?}

The CNB holds a larger volume of foreign exchange reserves (FER) in major world currencies which is mainly a result of the exchange rate commitment. On the other hand, it holds a relatively small amount of gold which was largely disposed of in 1997-1998. Gold volumes are steadily decreasing and in November 2017 the CNB had only 9.33 tons of gold (CNB, 2017c).

\subsection{The Volume and Reasonable Amount of FER}

The volume of FER has almost quadrupled since the start of foreign exchange interventions (3.75x higher), reaching CZK 3,355.3 billion in April 2017. During the period of maintaining the fixed exchange rate the $\mathrm{CB}$ intervened in a total volume of approximately CZK 2.46 trillion.

The Czech Republic has one of the highest FER worldwide in proportion to its GDP. In April 2017 its FER reached the maximum and climbed to $70 \%$ of GDP of the year 2016 . Thus, the Czech Republic has reached the top of the amount of FER among developed countries. 


\section{Figure 4: The FER of CNB in millions of CZK}

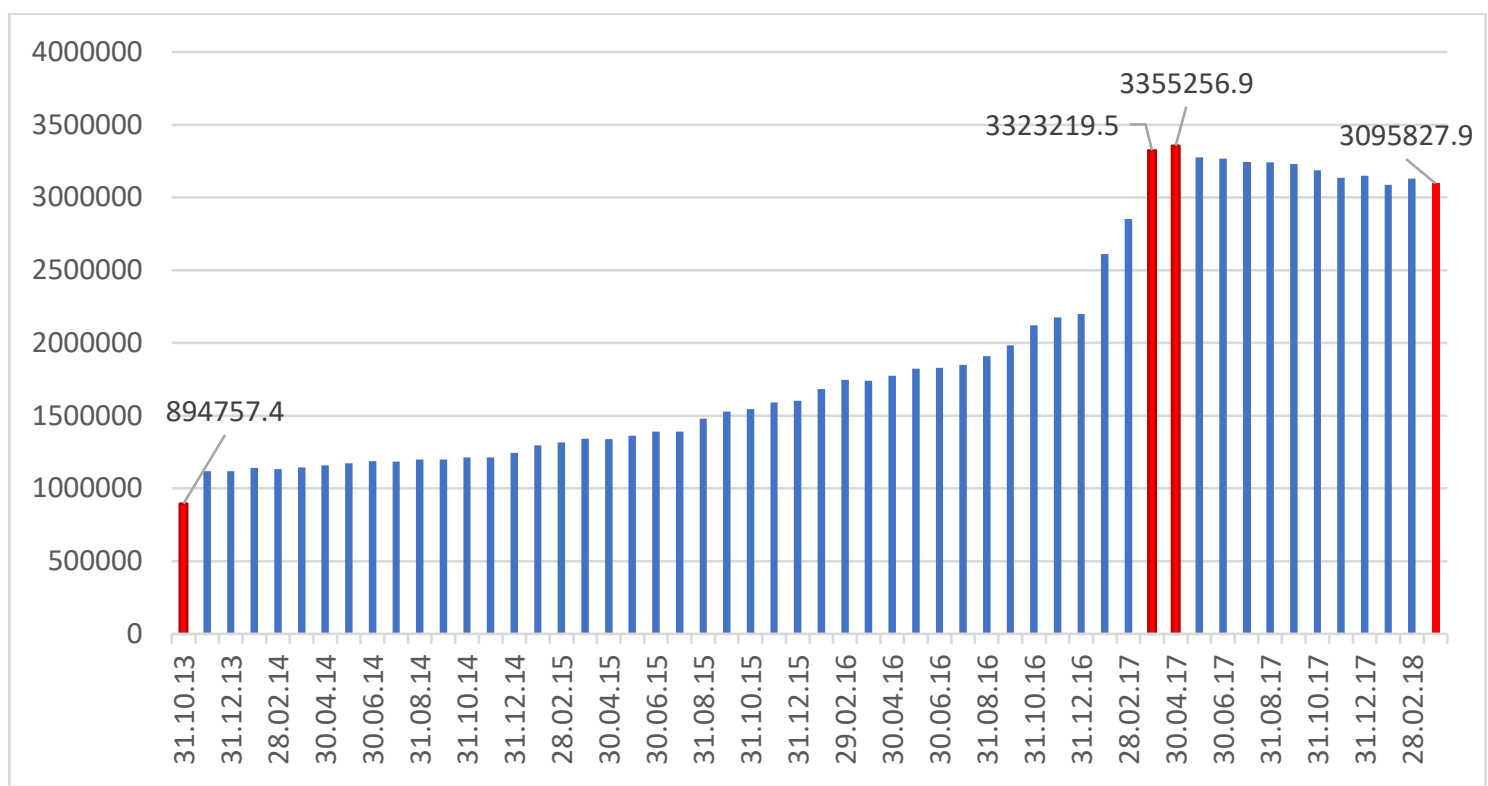

Source: CNB, Foreign exchange reserves (gross since January 2012), own processing

The basic rule for assessing the reasonable amount of FER is the so-called GuidottiGreenspan rule, according to which the FER should be equal to the country's short-term foreign liabilities as "... this indicator reflects the country's ability to manage its existing short-term debt (up to 1 year), in the case that external financing conditions will get worse (Sedláček, 2010, p. 5)."

In this sense, the Czech FER considerably exceed the requirements of the abovementioned rule. While in March 2017 the Czech crown equivalent of the total short-term external debt of the Czech Republic was CZK 1,217 billion, on the same date the value of FER was about CZK 3,323 billion, which is almost three times higher. Thus, if the Czech Republic faced a 30\% appreciation of the currency, as it was in the case of Slovakia, this would mean a loss for the Czech Republic of more than CZK 1,100 billion. Otherwise, observing the rule, the appreciation would result in losses of one third, i.e. about CZK 350 billion.

The reasonable amount of FER can also be analysed with respect to the monthly import volume. The calculation leads to the number of months that FER should be able to finance imports. According to this rule the amount of FER should be the 3-4 multiple of monthly import (Green \& Torgerson, 2007).

The volume of imports in March 2017 amounted to CZK 310 billion, which is less than 11 months in terms of the above calculation. Even given the exceeding of this recommendation rule, it can be concluded that FER are greatly exceeded. The ideal volume of FER, in this case, would have been around CZK 1,085 billion.

As a result of foreign exchange interventions, the CNB opened the foreign exchange position and adopted a strong exchange rate risk. During the intervention the euro was purchased at a rate of more than $27 \mathrm{CZK} / \mathrm{EUR}$, while the appreciation of the Czech 
crown has been already seen after the exit from the exchange rate commitment in April 6, 2017. Every such crown will bring the CNB a loss. The exchange rate of CZK/EUR has already (from the exit) appreciated by $7 \%^{3}$, which is a huge loss for the CNB. A major risk for the economic development of the CNB is the volume of FER where each appreciation of the Czech crown means a significant loss.

The idea of the Czech Republic's transition to the euro also emerged with the planned exit from the exchange rate commitment. However, this would mean a one-off conversion from CZK to EUR at a rate that would be out of control of the CNB, as the European Commission together with the ECB (European Central Bank) determines the value of the entry rate into the Eurozone after the exchange rate has been verified. With regard to the example of Slovakia, which struggled with a 30\% appreciation of the currency since their entry into the ERM II in connection with the changeover to the euro, this would mean a loss of more than CZK 1.5 trillion in the case of the Czech Republic. The CNB has been attacked by the ECB's Convergence Reports over the past few years due to negative own funds, which may adversely affect CB's ability to carry out its tasks (CNB, 2010). As a result of foreign exchange interventions, the CNB has already been in cumulative negative values - as in December 31, 2017 the loss for the accounting period amounted to CZK -243,243 million, while share capital and reserve funds of only CZK 61,480 million. (CNB, 2017a).

\section{Conclusion}

Within the CNB's assessment of the introduction of the exchange rate commitment, it is necessary to take into account that the real consequences will only manifest in the long run. From a short-term view, the foreign exchange interventions could have helped the Czech economy, in the long run, this cannot be assessed with certainty. As a result of exchange rate interventions, a huge amount of liquidity has emerged on the market that pushes asset prices up and now no one can safely say what the next development will be and whether new bubbles are not being created.

In connection with the introduction of the exchange rate commitment due to the reduction of the basic interest rates on the technical zero, the question is whether the interventions in the market rate was the right decision in the context of the fiscal and monetary policy mismatch that prevailed at that time, and with limited effect with respect to transmission under reduced demand. The government measures to consolidate public finances in the past negated the CNB's efforts to relax the monetary conditions as domestic demand was hindered by tax hikes which helped deepen the cyclical downturn in the economy. The CNB has gradually exhausted its basic MP tool by gradually lowering its basic interest rates and due to has been unable to influence inflation in the next coming years in an effective way.

${ }^{3}$ The Exchange rate in April 6, 2017 was around 27,06 CZK/EUR, while in April 18, 2018 was around 25,3 CZK/EUR. 
At the moment of the beginning of foreign exchange interventions, the Czech economy was moving below the level of potential product as a result of the recession, according to the theory of absorption, the foreign exchange interventions should have been effective in order to revive the economy. But the economy is much more complex than in order to be able to rely on just one monetary policy decision. It is no wonder, therefore, that the exchange rate measure had rather smaller than the major impact on the turnover of the economy. Changes in the economy could not have been the result of exchange rate interventions, since they began about 2-3 quarters before the exchange rate commitment was even introduced.

In the course of 2014, the effect of the exchange rate commitment on GDP growth cannot be ruled out. However, according to the development of GDP growth (20112016), it can be assumed that growth was mainly due to the change of economic cycle.

The transmission of MP in the regime of using the exchange rate is faster (roughly by half) than in the case of using the interest rates. Therefore, if the use of the exchange rate commitment was as legitimate as the CNB had argued and subsequently properly set, the inflation rate should be at its inflation target at the latest by the end of 2014 . However, the further extension of the exchange rate commitment and the postponement of the exit with respect to the next years did not have the inflation impact, as might be the case of using basic interest rates.

The risky result is a significant increase in FER to almost four multiple. The subsequent losses due to the further appreciation of the Czech crown may be risky to the CNB's credibility.

In connection with the introduction of the exchange rate commitment, it is necessary to mention side effects. One of them is a huge amount of FER, which exceeded several times the standard measure tools for assessing the reasonable volume of FER. It can be said that the Czech Republic has been significantly over-sized as regards volumes of FER and, in the event of a steady appreciation of the domestic currency, the CNB will be facing more cumulative losses than it currently has.

The CNB holds FER not only in major world currencies but also in the form of bonds and shares, thereby becoming a participant in the capital market, and securities are not an appropriate instrument, it may pose a risk of uncertain yields or future losses.

Although the IMF the use of the exchange rate commitment rates positively, e.g. the BIS is not that positive, it is not excluded that it may be mistaken. Taking into account the devaluation of the Czech crown during the transformation, it was possible to listen to a whole series of recommendations from the IMF regarding the greater than the final devaluation that proved to be sufficient.

Although the IMF the use of the exchange rate commitment rates positively, e.g. the BIS is not that positive, it is not excluded that it may be mistaken. Taking into account the devaluation of the Czech crown during the transformation, it was possible to listen to a whole series of recommendations from the IMF regarding the larger than the final devaluation that proved to be sufficient. 
Measures during the last crisis were different than in the previous one. Non-traditional MP tools have been used. The more pronounced negative effects of these measures may deepen the discussion about the limitation of the excessive independence of the monetary authorities, and therefore the CB.

The paper was carried out with the financial support of the Grant Agency of the University of Economics (VSE IGS F5/2/2018).

\section{Reference}

CHRISTELIS, D., GEORGARAKOS, D., JAPPELLI, T., VAN ROOIJ, M. (2016). Trust in the Central Bank and Inflation Expectations. Amsterdam: De Nederlandche Bank NV. [online] Available at: https://www.dnb.nl/en/binaries/Working\%20paper\%20537 tcm47-350253.pdf [Accessed 4 May. 2017].

CNB (2010). The Czech National Bank Disagrees with the ECB Convergence Report. [online] Available at:

https://www.cnb.cz/cs/verejnost/pro media/tiskove zpravy cnb/2010/20100512 convergence.ht ml [Accessed 16 Sep. 2017].

CNB (2017). About CNB. [online] Available at: http://www.cnb.cz/cs/o cnb/ [Accessed 12 Aug. 2017].

CNB (2017a). CNB - Dekade Balance of the $4^{\text {th }}$ Quarter of the Year 2017. [online] Available

at:

https://www.cnb.cz/cs/o cnb/hospodareni/dekadni bilance/dekadni bilance archiv/2017/dekady q4 2017.html [Accessed 16 Sep. 2017].

CNB (2017b). Foreign Exchange Reserves (Gross since January 2012). [online] Available at: http://www.cnb.cz/cnb/STAT.ARADY PKG.PARAMETRY SESTAVY?p sestuid=29428\&p strid= ADC\&p lang=CS [Accessed 11 Aug. 2017].

CNB (2017c). Foreign Exchange Reserves - Structure. [online] Available at: https://www.cnb.cz/cs/statistika/platebni bilance stat/devizove rezervy/drs struktura.htm [Accessed 12 Dec. 2017].

CNB (2017d). Investment Position and Indebtedness of the Czech Republic Compared to Foreign Countries. [online] Available at: https://www.cnb.cz/cs/statistika/platebni bilance stat/investicni pozice/ip komentar.html [Accessed 12 Aug. 2017].

CNB (2017e). Monetary Policy Instruments. [online] Available at: https://www.cnb.cz/cs/menova politika/mp nastroje/ [Accessed 24 Nov. 2017].

Czech Press Office (2016). Head of Brano Group: CNB Interventions for as Long as Possible, But the Ideal is the Euro. [online] Available at: https://www.tyden.cz/rubriky/byznys/cesko/sef-brano-groupintervence-cnb-co-nejdele-idealem-je-ale-euro 400402.html [Accessed 8 Jul. 2017]. 
CZSO (2013). What Does the High Import Intensity of the Czech Economy Mean. [online] Available at: https://www.czso.cz/documents/10180/20533812/csav121613.pdf/1608be60-b9e0-4403-96e88e2a5e6f6875?version=1.0 [Accessed 10 Aug. 2017].

CZSO (2017a). Foreign Trade in Goods - National Concepts - Time Series. [online] Available at: https://www.czso.cz/csu/czso/vzonu cr [Accessed 12 Aug. 2017].

CZSO (2017b). Main Macroeconomic Indicators. [online] Available at: https://www.czso.cz/csu/czso/hmu cr [Accessed 20 Jul. 2017].

ČížEK, B. (2013) Foreign Exchange Interventions and Position of the Industry and Transport Union of the Czech Republic. The Industry and Transport Union of the Czech Republic. [online] Available at: http://www.spcr.cz/projekty/probihajici-projekty/144-media/aktualni-komentare/6870-devizoveintervence-a-pozice-svazu-prmyslu-a-dopravy-r [Accessed 8 Jul. 2017].

DOMINGUEZ, K. M. (1998). Comments and Discussion on 'It's Baaack! Japan's Slump and the Return of the Liquidity Trap'. Brookings Papers on Economic Activity 2.

EGGERTSON, G. B. (2006). The Deflation Bias and Committing to Being Irresponsible. Journal of Money, Credit and Banking, Vol. 38, No. 2. Ohio: State University Press, pp. 283-321.

GREEN, R., TORGERSON, T. (2007). Are High Foreign Exchange Reserves in Emerging Markets a Blessing or a Burden? Department of the Treasury: Office of International Affairs, Occasional Paper No. 6. [online] Available at: http://rag8.web.rice.edu/TreasuryOccasionalPaperNo6.pdf [Accessed 16 Sep. 2017].

MLČochoVÁ, J. (2012). Řežábek: Fiscal Policy Partly Negates the Central Bank's Effort. New York: Thomson Reuters. Aonline] Available at: https://www.cnb.cz/cs/verejnost/pro media/clanky rozhovory/media 2012/cl 12121024 rezabe k reuters.html [Accessed 20 Jul. 2017].

NATIONAL BANK OF SLOVAKIA (2017). 2005-2008 (Inflation Targeting in ERM II). (2017). [online] Available at: https://www.nbs.sk/sk/menova-politika/menova-politika-nbs-do-roku-2009/20052008-inflacne-cielenie-v-erm-ii [Accessed 11 Dec. 2017.

OECD (2017). Import Content of Exports. [online] Available at: https://data.oecd.org/trade/import-contentof-exports.htm\#indicator-chart [Accessed 17 Aug. 2017].

OECD (2017). Quarterly GDP. [online] Available at: https://data.oecd.org/gdp/quarterly-gdp.htm [Accessed 9 Aug. 2017].

OKINA, K. (1999). Monetary Policy under Zero Inflation: A Response to Criticisms and Questions Regarding Monetary Policy. Monetary and Economic Studies, Institute for Monetary and Economic Studies, Bank of Japan, pp. 157-182.

SEDLÁČEK, P. (2010). State Investment Funds - an Important Institutional Investor in Global Financial Markets. Acta Oeconomica Pragensia, p. 22.

SVENSSON, L. (2001). The Zero Bound in an Open-economy: A Foolproof Way of Escaping from a Liquidity Trap. Monetary and Economic Studies 19, pp. 277-312. 
WOODFORD, M. (1999). Commentary: How Should Monetary Policy Be Conducted in an Era of Price Stability? New Challenges for Monetary Policy, Reserve Bank of Kansas City.

ZAVADILOVÁ, T. (2014). Each member of the Bank Board of Directors Is Otherwise Sensitive. CNB. [online] Available at: https://www.cnb.cz/cs/verejnost/pro media/clanky rozhovory/media 2014/cl 14140304 rezabe k e15.html [Accessed 14 Dec. 2017]. 